\title{
Remittances, financial development and economic growth in sub-Saharan African countries: evidence from a PMG-ARDL approach
}

\author{
D. O. Olayungbo* (1) and Ahmod Quadri
}

* Correspondence:

doolayungbo@oauife.edu.ng;

doolayungbo@gmail.com

Department of Economics, Obafemi

Awolowo University, Ile-Ife, Nigeria

\begin{abstract}
The study investigated the relationship among remittances, financial development and economic growth in a panel of 20 sub-Saharan African countries over the period of 2000 and 2015. The study used both Pooled Mean Group and Mean Group/ARDL estimations with panel unit root and cointegration tests. After establishing cointegration, remittances and financial development were found to have positive effects on economic growth both in the short and the long run. The interactive term showed that financial development acted as a substitute in the remittances-growth relationship. Finally, unidirectional causal relationships were found to exist from GDP to remittances and from financial development to GDP. However, no causality existed between remittances and financial development in the SSA countries.
\end{abstract}

Keywords: Remittances, Financial development, Growth, PMG/MG-ARDL, Granger causality test, African countries

JEL: F22, F24, J61

\section{Introduction}

Remittances naturally come from migration as basic gains and compensations to the emigrant countries for losing part of their labour force (Blouchoutzi and Nikas, 2014). It has been adjudged as a faster, easier and cheaper mode of transferring money around the world (Imai et al., 2014; World Bank, 2014). Globally, there were over 244 million international migrants in 2015, of which $58 \%$ and $42 \%$ lived in developed and developing regions respectively (International Migration Report, 2015). The remittances that flowed to developing countries in 2001 totaled $\$ 96.5$ billion with $\$ 14$ billion to Africa, it increased to $\$ 331.7$ billion in 2010 with $\$ 40$ billion to Africa, $\$ 416.6$ billion in 2013, $\$ 429.9$ billion in 2014 and it rose to $\$ 432$ billion in 2015 out of which $\$ 52$ billion flowed to Africa (Migration and Remittances, 2016). During the same period, Africa recorded average economic growth of $5 \%$ in 2001 and about $5.5 \%$ growth rate between 2010 and 2015. These figures were well above its Asian and Middle East counterparts with an average growth rate of $5 \%$ and less than $5 \%$ between the same period respectively (The Economist, IMF, 2018). In order words economic growth has

(C) The Author(s). 2019 Open Access This article is distributed under the terms of the Creative Commons Attribution 4.0 International License (http://creativecommons.org/licenses/by/4.0/), which permits unrestricted use, distribution, and reproduction in any medium, provided you give appropriate credit to the original author(s) and the source, provide a link to the Creative Commons license, and indicate if changes were made. 
grown as remittance inflow and it is worthwhile to explore the relationship between them. The lowest growth rate of remittances was however, recorded in 2015 after the occurrence of the global financial crisis of 2008 and 2009. Difficult economic situations in major remittance-source countries have been identified as the major reasons for the slower growth rate of remittance in 2015 (Migration and Remittances, 2016). As documented empirically by (Yaseen, 2012), remittances are positively correlated with financial development through the deposit flow of remittances received abroad to the home banks. Financial development proxy by broad money has exhibited several patterns in the selected countries coupled with their GDP growth rate. The broad money (\% GDP) in Senegal, Mali and Gambia amounted to 45.2, 32.9 and 57.9 respectively but with $3.9 \%, 7.2 \%$ and $-0.2 \%$ GDP annual growth rate in 2014 (WDI, 2015). The scatter diagram plotted for remittances and the GDP of sub-Saharan African (SSA) countries in Fig. 1, implies that the proportion of remittances has been dynamic and decreasing with increase in GDP. The scatter diagram implies negative and dynamic relationships between remittance inflow and the level of GDP in the SSA countries. Table 1, however, shows that remittance inflow to SSA has been more stable compared to other foreign inflows, which suggests possible effects on the economic growth of SSA countries. Remittance inflows to developing countries are more than three times official development aid (ODA) and even bigger than foreign direct investment (FDI) inflows with the exclusion of China (Migration and Remittances, 2016). Also compared to other monetary flows, remittances are countercyclical in the sense that the flow of money increases even when financial markets decline (Ratha, 2013). Therefore, according to the World Bank (2017), remittances represent the largest source of foreign flows to SSA after FDI. For instance, in 2015, Nigeria occupied the 6th position among the top 10 remittance recipients in the world with $\$ 20.8$ billion (Migration and Remittances, 2016). This accounted for $4.4 \%$ of the Nigeria's GDP with an average GDP growth rate of $6.8 \%$ from 2011 to 2015 (WDI, 2017). Senegal received over \$16 billion of remittances in 2011 with positive GDP growth of $1.8 \%$ which was above Mali's over $\$ 7$ billion receipt of remittances in the same year with GDP growth rate of 3.2\% (WDI, 2015). Lesotho received almost $\$ 5$ billion remittances in 2013 representing 22\% of her GDP with GDP

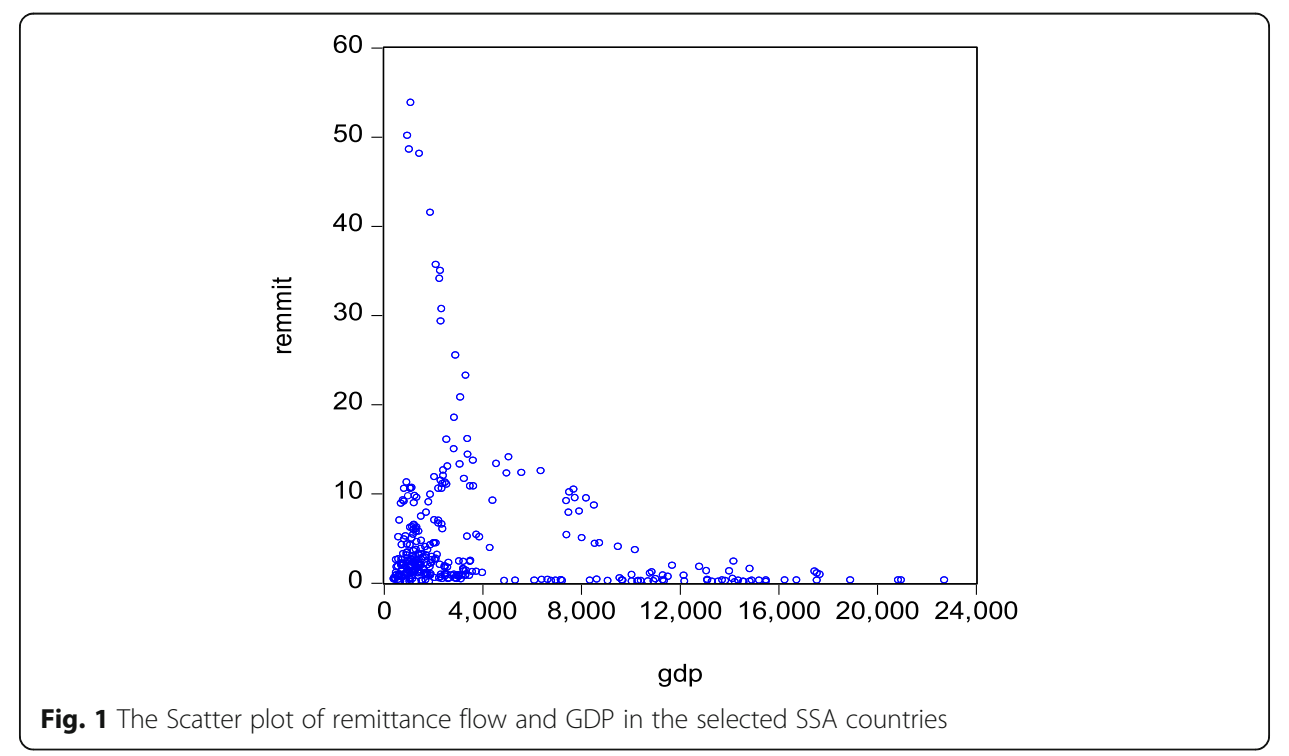


Table 1 Percentage growth of Remittances and other monetary flows in Sub-Sahara African countries

\begin{tabular}{llllllllllll}
\hline Flows & 2000 to 2003 & 2004 to 2006 & 2007 & 2008 & 2009 & 2010 & 2011 & 2012 & 2013 & 2014 & 2015 \\
\hline Remittances & -4.96 & 71.82 & 10.86 & 10.17 & -0.28 & 9.96 & 14.4 & 1.24 & 0.35 & 1.59 & 7.95 \\
FDI & 41.43 & 10.7 & 82.54 & 29.87 & -6 & -22.7 & 43.7 & -9.88 & 5.03 & 15.51 & -5.47 \\
ODA & 3.23 & 18.57 & -13.6 & 13.08 & 9.44 & 0.45 & 6.74 & -2.49 & 3.41 & -2.31 & - \\
\hline
\end{tabular}

World Development Indicators 2017

growth rate of 2.3\% (WDI, 2015). However, in spite of the huge flow of remittances to African countries, to the best of our knowledge, specific studies to date that have examined the dynamic relationship among remittances, financial development and economic growth for SSA countries are rare. The few known available studies for SSA are Kumar (2012) done for the period of 1970 to 2010 and even the more recent ones are Adarkwa (2015) employed individual linear regression for 4 SSA countries between year 2000 to 2010. Also, Coulibaly (2015) applied panel granger causality testing approach based on seemingly unrelated regression (SUR) for 19 SSA countries investigated from 1980 to 2010. Specifically, this study adopted pooled mean group (PMG) autoregressive distributed lag (ARDL) model and compared the results with the mean group (MG) ARDL developed by Pesaran, Shin and Smith (1999) and Pesaran and Shin (1995) for short run and long run panel analysis. With the dynamic model, we were able to examine a dynamic panel analysis for the selected African countries and also test for the interactive effects of remittances and financial development on growth. Finally, we investigated possible feedback effects among remittances, financial development and growth for SSA countries using Granger VAR block exogeneity test. Our result shows that remittances contribute positively and significantly to economic growth in SSA. Moreover, the interactive effects show a substitute relationship between remittance flow and financial development. Finally, the interactive term validates the absence of causal relationship between financial development and remittances in SSA. The rest of the paper is as follows. Literature review section reviews the literature, section 3 gives the theoretical model, data source, descriptive statistics, panel unit roots and the cointegration tests, section 4 presents the robustness results, causality test while the last section concludes and recommends.

\section{Literature review}

There are some theories on labour migration and remittances, such theories are the optimistic perspective, pessimistic view, two gap model and the endogenous theoretical model. Some prominent scholars who subscribe to the optimistic view include; Kindleberger (1965), Todaro (1969), Beijer (1970) and Massey et al. (1993). According to this view of the 1950 s and 1960s in development theory, return migrants were seen as important agents of change and innovation. It was expected that the migrants not only bring back money but also new ideas, knowledge and entrepreneurial attitudes and as such migrants were expected to play a viable role in the developmental process (De Haas, 2010). From this perspective, migrants' remittances are deemed important since they bring about change in households incomes, promote investments and innovations and thereby aiding the larger economy of the migrants' country of origin in its economic take off (Kindleberger, 1965; Beijer, 1970 and De Haas, 2007). The pessimistic view emerged in the 1970s 
and 1980s and argued that migration and remittances create underdevelopment in migrants' countries of origin (Olufemi and Ayandibu, 2014). Remittances make receiving countries dependent on the sending countries as well as making receivers of remittances dependent on the sender (Binford, 2003). This often leads to moral hazard on the part of the receiving countries. Associated with this view are Lipton (1980), Rubenstein (1992), Russell (1992) and Binford (2003).

Conflicting and contradicting empirical evidence have been reported concerning the nexus among remittances, financial development and economic growth. This is evident in the studies carried out on a specific country, region or various countries. Empirically, some studies have shown that remittances do not serve as a significant source of capital for economic development and therefore, there is no significant relationship between remittances and economic growth in developing countries (Karagoz, 2009 for Turkey; Siddique et al., 2010 for Bangladesh, India and Sri Lanka; Feeny et al., 2014 for Small Island Developing States (SIDs) in SSA, the Pacific, Latin America and the Caribean). Scholars have also examined the nature of relationship between remittances and financial development using both time series and panel data. To some, remittances complement financial development, that is remittances thrive in countries with well-developed financial system (Aggarwal et al. 2011 for 109 developing countries, Kratou and Gazdar, 2016 for Middle East and North Africa (MENA) countries; Akonji and Wakili, 2013 for Nigeria), while others postulated that remittances provide an alternative way to finance investment and help to overcome liquidity constraints (Giuliani and Ruiz Arranz, 2009 for 100 developing countries; Fayissa and Nsiah, 2010 for Latin America; Sobiech, 2015 for 60 developing countries). In addition, there are recent studies that have examined the relationship among remittances, financial development and economic growth (Levine et al., 2000 for developing countries; Cooray, 2012 for South Asia; Pearce and Pelesai, 2013 for Nigeria; Sibindi, 2014 for Lesotho; Kibet and Agbelenko, 2015 for West African Economic and Monetary Union (WAEMU); Barua and Rana, 2015 for Southern Asia countries.

Mundaca (2009) developed a theoretical model for analyzing the effects of remittances and financial market development, as well as their interrelationship on economic growth. The model was tested on a panel data set for countries in Latin America and the Caribbean over the period of 1970 to 2002. The results showed that remittance contributed positively to economic growth in the two regions. In addition, Giuliani and Ruiz Arranz (2009) analyzed the relationship between remittances and growth and its interaction with the financial development in the recipient country using a newly constructed cross-country dataset for remittances covering about 100 developing countries over the period of 1975 to 2002. Remittances were found to promote growth in less financially developed countries by providing an alternative way to finance investment. Esteves and Khoudour-casteras D (2011) added to the understanding of multiple impacts of the mass migration phenomenon on the economies of emigration countries. The study investigated the impact of remittances and other international capital flows on financial development during the mass migration period of 1870 to 1913 . The results showed that migrants' transfers over the study period were more relevant in promoting the domestic financial sector than other international capital flows. Fiyissa and Nsiah (2010) explore the aggregate impact of remittances on economic growth of 18 Latin American countries within the conventional neo-classical growth framework 
using an unbalanced panel data spanning from 1980 to 2005. The study also investigated the effect of remittances relative to the other external sources of capital such as foreign aid and foreign direct investment on the economic growth and development of Latin America countries. The results showed that remittances have a positive and significant effect on the growth of Latin American countries where the financial systems are less developed by providing an alternative way to finance investment and helping overcome liquidity constraints. Motelle (2011) examined the effect of remittance on financial development in Lesotho. Co-Integration test is performed and Vector Error Correction Model (VECM) was used to observe the dynamic relationship. The results showed that remittances tend to have a long run effect on financial development. The Granger causality test revealed that financial development Granger caused remittances. In another work, Cooray (2012) carried out an empirical investigation of the influence of migrant remittances on two dimensions of the financial sector namely; size and efficiency using a sample of 94 non-OECD countries. The results suggested that migrant remittances contributed to increasing the size and efficiency of the financial sectors in the sample countries. Yaseen (2012) used a panel data set during the period of 2000 to 2010 in a sample of MENA countries (Algeria, Egypt, Jordan, Libya, Morocco, Oman, Syria, Lebanon, and Tunisia). Using fixed effects approach, the empirical analysis points to the fact that institutions and financial development play an important role in how remittances affect economic growth. In general, the evidence indicates a larger contribution of remittances flow to domestic resources. Imai et al. (2014) re-examined the effects of remittances on the growth of GDP per capita using annual panel data for 24 Asia and Pacific countries from 1980 to 2009. The analysis also shows that the volatility of capital inflows such as remittances contribute to better economic performance and are also a source of output shocks. Remittances also contribute to poverty reduction especially through their direct effects.

Cooray (2012), using a panel data over 1970 to 2008 for Asia countries, investigated the impact of migrant remittances on economic growth in South Asia. The effect of remittances on economic growth was found to be positive. The results also show that increased openness could encourage increased transfer into remittance receiving countries and also increase the use of the formal sector for money transmission. Akonji and Wakili (2013) examined the impact of net migrant remittance on economic growth having taken into consideration the cost of transferring the remittances Timer series data on Nigeria between 1980 to 2010 was used. The study employed the use of seemingly unrelated regression (SUR) analysis and error correction model (ECM). The results established a significant relationship between net remittance and economic growth but at individual level, it provided immediate income for different household. The study concluded that remittances contributed significantly to economic growth in Nigeria.

Keong Choong and Yin Koay (2013) investigate the nexus between remittance and economic growth taking into account, the development in financial sector in Malaysia over the period of 1975 to 2009. The results showed that remittances and financial development are statistically significant in affecting the economic growth in Malaysia in both short run and long run. Furthermore, the Granger causality tests also show that financial development statistically and significantly affects the remittances inflows in the short run. Gazdar and Kratou (2012) examined the effect of remittances on economic growth in a panel of 24 African countries over the period of 1998 to 2011 . The 
System Generalized Method of Moments (SGMM) was used and a complementarity between financial development and remittances in economic growth was found such that remittances was growth enhancing in countries with developed financial sectors. Sibindi (2014) studied the causal relationship among remittances, financial development and economic growth in Lesotho for the period of 1975 to 2010. Per capita remittances, real per capita, broad money supply and real per capital gross domestic product as the proxies for remittances, financial development and economic growth respectively. Johansen procedure was employed to test for co-integration among the variables and Granger causality test was based on vector error correction model (VECM). The results suggested that remittances cause economic growth without feedback and financial development causes remittances without feedback. On the other hand, Sobiech (2015) studied the importance of remittances and financial development for 54 developing countries using a panel data for 1970-2010. The study estimated a financial sector development index and uses it to determine the relevance of finance as a transmission channel for remittances to affect economic growth. The index brings together information from existing measures reflecting sizes, depth and efficiency of the financial sector. The Panel Generalized Method of Moments (GMM) used showed a negative effects of remittances on economic growth of the sampled countries. Kibet and Agbelenko (2015) examined the relationship between financial development and economic growth in West African Economic and Monetary Union (WAEMU) for the period 1981 to 2010. General Moment method (GMM) was used and a positively and statistically significant effect of financial development on economic growth was established. The causality between the two is also bi-directional, thereby supporting both supply-leading and demand-following hypotheses. In examining the association between remittances received and how they affect the availability of credit to private sector, bank deposits intermediated by financial institutions and money supply, Karikari et al. (2016) explored the traceable causality between remittances and financial developments in some countries in Africa. A panel data on remittance flows to 50 developing countries in Africa from 1990 to 2011 were used. The study used fixed effects and random effect estimations as well as Vector Error Correction Model method on the panel data. The findings generally indicated that remittances positively and significantly influence financial development. Chowdhury (2016) examined the effects of remittances and financial development on economic growth for 33 top remittance recipient developing countries using different measures of financial development from the year 1979 to 2011. The study estimated the basic neoclassical Solow growth model in a dynamic panel setting with the two- step general method of moments (GMM). After testing the stationarity process of the data, the study found remittances to significantly promote economic growth in the sampled countries. Finally, insignificant impact of financial development was found on the remittance-growth nexus.

\section{Gap in the literature}

The empirical literature reviewed above shows that previous studies have extensively focused on the relationship between remittances and financial development and how these two variables impact economic growth as well as other macroeconomic variables in developing countries. However, empirical investigation on the effects of remittances on economic growth using financial development as a transmission channel have not received 
adequate priority in the SSA countries. Furthermore, previous research works have not explicitly examined the short run and long run effects of remittances and financial development on economic growth in less-developed economies in general and SSA countries in particular. This study therefore intends to contribute to literature by filling this gap.

The summary of the literature review on the relationship among remittances, financial development and economic growth is presented in tabular form in Table 2.

\section{Theory and model framework}

The basic argument of the two-gap model of Harrod-Domar is that most developing countries face either a shortage of domestic saving to match investment opportunities or a shortage of foreign exchange to finance needed import of capital and intermediate goods (Todaro and Smith, 2012). Two gap analysis of foreign assistance implies that external finance (loans, grants or remittances) can play a critical role in supplementing domestic resources in order to relieve savings or foreign exchange bottlenecks. This paper adopts the saving-investment theoretical gap framework of Harrod-Domar growth model which was further popularized by Chenery and Strout (1966). The theory presumes that developing countries can use foreign inflow of funds in which remittances is among, to achieve equilibrium in their saving investment gap. From the two-gap model, we have at equilibrium saving equals investment at all time as:

$$
S_{t}=I_{t}
$$

However, in reality, actual saving is usually less than investment in African countries (saving gap); therefore, remittances can serve as external funds used to augment the low saving level with investment as:

$$
S_{t}+\text { remit }_{t}=I_{t}
$$

The capital stock equation where capital stock depends on saving can then be written as:

$$
K_{t}=S_{t}+\text { remit }_{t}+(1-\delta) K_{t-1}
$$

In which case, the Cobb- Douglas production function that links capital stock, technology and labour to output is written as:.

$$
Y_{t}=A L_{t}{ }^{1-\alpha} K_{t}^{\alpha}
$$

Where $Y_{t}$ is the gross domestic product (GDP); $L_{t}$ is labour and $K_{t}$ is the capital stock.

In per capita terms, Eq.(4) can be written as:

$$
\begin{aligned}
& \frac{Y_{t}}{L_{t}}=\frac{A L_{t}{ }^{1-\alpha} K_{t}{ }^{\alpha}}{L_{t}} \\
& \frac{Y_{t}}{L_{t}}=A\left(\frac{K_{t}}{L_{t}}\right)^{\alpha}
\end{aligned}
$$

Eq. (6) can further be written as:

$$
y=A k^{\alpha}
$$

Where $y=Y / L, k=K / L, y$ is output per labour, $A$ is the exogenous technology taken as given and $k$ is capital per labour ratio. 
Table 2 Tabular Summary of the Literature Review

\begin{tabular}{|c|c|c|c|c|}
\hline Author/Year & Sample & Variables Employed & Methodology & Outcomes \\
\hline $\begin{array}{l}\text { Chami } \\
\text { et al. (2003) }\end{array}$ & $\begin{array}{l}113 \text { countries, } \\
1970 \text { to } 1998\end{array}$ & $\begin{array}{l}\text { Remittance /GDP, } \\
\text { M2/GDP and GDP per capita }\end{array}$ & Panel OLS & $\begin{array}{l}\text { Negative effects of } \\
\text { remittances on growth }\end{array}$ \\
\hline Faini (2005) & Europe and USA & $\begin{array}{l}\text { Migration figure, Remittances/ } \\
\text { GDP and Poverty }\end{array}$ & Questionnaire & $\begin{array}{l}\text { Positive effects of } \\
\text { remittances on growth. }\end{array}$ \\
\hline $\begin{array}{l}\text { Giuliano and } \\
\text { Ruiz-Arranz } \\
\text { (2005) }\end{array}$ & $\begin{array}{l}100 \text { countries, } \\
1975 \text { to } 2002\end{array}$ & $\begin{array}{l}\text { Remittances/GDP, M2/GDP, } \\
\text { private credit to GDP } \\
\text { and GDP per capita }\end{array}$ & Panel OLS & $\begin{array}{l}\text { Positive effects of } \\
\text { remittances on growth. }\end{array}$ \\
\hline $\begin{array}{l}\text { Richard } \\
\text { et al. (2005) }\end{array}$ & $\begin{array}{l}71 \text { Developing } \\
\text { countries } 1987 \\
\text { to1996 }\end{array}$ & $\begin{array}{l}\text { Gini Coefficient, Per capita } \\
\text { GDP and International } \\
\text { Migration figure. }\end{array}$ & $\begin{array}{l}\text { Pooled OLS } \\
\text { and IV Estimate }\end{array}$ & $\begin{array}{l}\text { International Migration } \\
\text { and remittances reduce } \\
\text { poverty }\end{array}$ \\
\hline $\begin{array}{l}\text { Guilano and } \\
\text { Ruiz-Arranz } \\
\text { (2009) }\end{array}$ & $\begin{array}{l}100 \text { Developing } \\
\text { countries }\end{array}$ & $\begin{array}{l}\text { Remittances/GDP Private } \\
\text { credit to GDP and Investment }\end{array}$ & IV Estimate & $\begin{array}{l}\text { Positive effects of } \\
\text { remittances on Growth. }\end{array}$ \\
\hline Karagoz 2009 & $\begin{array}{l}\text { Turkey, from } \\
1970 \text { to } 2005\end{array}$ & $\begin{array}{l}\text { Remittances/GDP capital } \\
\text { formation/ GDP, FDI, } \\
\text { net private flow and FDI. }\end{array}$ & $\begin{array}{l}\text { Cointegration } \\
\text { and OLS }\end{array}$ & $\begin{array}{l}\text { Negative effects of } \\
\text { remittances on growth. }\end{array}$ \\
\hline $\begin{array}{l}\text { Siddique } \\
\text { et al. (2010) }\end{array}$ & $\begin{array}{l}1976 \text { to } 2006 \\
\text { Bangladesh, } \\
\text { India and Sri Lanks }\end{array}$ & $\begin{array}{l}\text { Per capita remittances, } \\
\text { Export and GDP } \\
\text { per capita }\end{array}$ & $\begin{array}{l}\text { VAR Granger } \\
\text { Causality test }\end{array}$ & $\begin{array}{l}\text { Two way causality test } \\
\text { existed in Sri Lanka. }\end{array}$ \\
\hline $\begin{array}{l}\text { Khan and } \\
\text { Azam (2011) }\end{array}$ & $\begin{array}{l}1995 \text { to } 2010 \\
\text { Azerbajan and } \\
\text { Armenia }\end{array}$ & Gdp and remittance/GDP & $\begin{array}{l}\text { Simple Log } \\
\text { Linear regression }\end{array}$ & $\begin{array}{l}\text { Positive effects of } \\
\text { remittances on growth }\end{array}$ \\
\hline $\begin{array}{l}\text { Jayaraman, } \\
\text { Choong and } \\
\text { Kumar (2011) }\end{array}$ & $\begin{array}{l}\text { Samoa and Tonga, } \\
1981 \text { to } 2008\end{array}$ & $\begin{array}{l}\text { Remittance to GDP, } \\
\text { M2/GDP, private sector } \\
\text { credit to gdp and FDI. }\end{array}$ & Bound Test & $\begin{array}{l}\text { Positive effects of } \\
\text { remittances } \\
\text { on growth. }\end{array}$ \\
\hline $\begin{array}{l}\text { Jayaraman, } \\
\text { Choong and } \\
\text { Kumar (2012) }\end{array}$ & $\begin{array}{l}1970 \text { to } 2009 \\
\text { Pacific Island }\end{array}$ & $\begin{array}{l}\text { Remittance/GDP per worker, } \\
\text { FDI and private sector } \\
\text { credit to GDP, }\end{array}$ & Bound Test & $\begin{array}{l}\text { Positive effects of } \\
\text { remittances on growth. }\end{array}$ \\
\hline $\begin{array}{l}\text { Javid et al. } \\
\text { (2012) }\end{array}$ & $\begin{array}{l}1973 \text { to } 2010 \\
\text { Pakistan }\end{array}$ & $\begin{array}{l}\text { Real GDP, remittance/GDP, } \\
\text { investment to GDP, income } \\
\text { inequality and trade openess. }\end{array}$ & ARDL & $\begin{array}{l}\text { Positive effects of } \\
\text { remittances on growth. }\end{array}$ \\
\hline Kumar (2012) & $\begin{array}{l}\text { Sub-Saharan Africa, } \\
1970 \text { to } 2010 .\end{array}$ & $\begin{array}{l}\text { Remittance/GDP, private sector } \\
\text { credit to GDP, telephone lines } \\
\text { per } 100 \text { people, and ODA } \\
\text { to GDP. }\end{array}$ & $\begin{array}{l}\text { ARDL Bound } \\
\text { Test. }\end{array}$ & $\begin{array}{l}\text { Negative effects of } \\
\text { remittances, Financial } \\
\text { Development and ICT } \\
\text { on growth }\end{array}$ \\
\hline $\begin{array}{l}\text { Nyamongo } \\
\text { et al. (2012) }\end{array}$ & $\begin{array}{l}\text { Africa, } 1980 \\
\text { to } 2009 .\end{array}$ & $\begin{array}{l}\text { GDP per capita, remittances } \\
\text { and financial development. }\end{array}$ & $\begin{array}{l}\text { Pooled OLS } \\
\text { fixed effect. }\end{array}$ & $\begin{array}{l}\text { Remittances promote } \\
\text { economic growth. }\end{array}$ \\
\hline $\begin{array}{l}\text { Cooray } \\
(2012)\end{array}$ & $\begin{array}{l}94 \text { Non-OECD, } \\
1990 \text { to } 2010\end{array}$ & $\begin{array}{l}\text { Remittances, financial sector } \\
\text { size and government bank } \\
\text { ownership. }\end{array}$ & $\begin{array}{l}\text { Pooled OLS } \\
\text { and System } \\
\text { GMM }\end{array}$ & $\begin{array}{l}\text { Remittances promote } \\
\text { financial sector } \\
\text { development. }\end{array}$ \\
\hline $\begin{array}{l}\text { Akonji and } \\
\text { Wakili (2013) }\end{array}$ & $\begin{array}{l}\text { Nigeria, } 1980 \\
\text { to } 2010 .\end{array}$ & $\begin{array}{l}\text { Real GDP per capita, } \\
\text { remittance/GDP } \\
\text { and M2/GDP }\end{array}$ & $\begin{array}{l}\text { Seemingly } \\
\text { unrelated } \\
\text { regression } \\
\text { (SUR) and ECM }\end{array}$ & $\begin{array}{l}\text { Remittances promotes } \\
\text { economic growth. }\end{array}$ \\
\hline $\begin{array}{l}\text { Akkoyunlu } \\
\text { (2013) }\end{array}$ & $\begin{array}{l}\text { Turkey, } 1963 \\
\text { to } 2009 .\end{array}$ & $\begin{array}{l}\text { Remittances/GDP, bank } \\
\text { deposit, private credit/GDP }\end{array}$ & $\begin{array}{l}\text { Toda Yamamoto } \\
\text { Non-Granger } \\
\text { Causality test. }\end{array}$ & $\begin{array}{l}\text { No causality between } \\
\text { financial development } \\
\text { and remittances }\end{array}$ \\
\hline $\begin{array}{l}\text { Koay and } \\
\text { Choog (2013) }\end{array}$ & Malaysia & $\begin{array}{l}\text { GDP remittance/GDP } \\
\text { and } \mathrm{M} 2 / \mathrm{GDP} \text {. }\end{array}$ & $\begin{array}{l}\text { ARDL and } \\
\text { Granger } \\
\text { Causality } \\
\text { test. }\end{array}$ & $\begin{array}{l}\text { Remittances promotes } \\
\text { growth and causality } \\
\text { runs from finance to } \\
\text { remittances }\end{array}$ \\
\hline $\begin{array}{l}\text { Alkhathlan } \\
\text { (2013) }\end{array}$ & $\begin{array}{l}\text { Saudi Arabia, } \\
1970 \text { to } 2010 .\end{array}$ & $\begin{array}{l}\text { Real GDP, Remittance/GDP } \\
\text { and Export. }\end{array}$ & ARDL & $\begin{array}{l}\text { Negative effects of } \\
\text { remittances on growth. }\end{array}$ \\
\hline $\begin{array}{l}\text { Meyer and } \\
\text { Shera (2013) }\end{array}$ & $\begin{array}{l}\text { Albania, } 1992 \\
\text { to } 2012 \text {. }\end{array}$ & $\begin{array}{l}\text { GDP, Remittance/ GDP } \\
\text { and M2/GDP. }\end{array}$ & ARDL and ECM & $\begin{array}{l}\text { Positive effects of } \\
\text { remittances on growth }\end{array}$ \\
\hline $\begin{array}{l}\text { Goschin } \\
\text { (2013) }\end{array}$ & $\begin{array}{l}\text { Romania, } 1994 \\
\text { to } 2011 .\end{array}$ & $\begin{array}{l}\text { GDP, Remittance/ GDP } \\
\text { and M2/GDP. }\end{array}$ & $\begin{array}{l}\text { Multi-factorial } \\
\text { regression } \\
\text { models }\end{array}$ & $\begin{array}{l}\text { Positive effects of } \\
\text { remittances on growth }\end{array}$ \\
\hline
\end{tabular}


Table 2 Tabular Summary of the Literature Review (Continued)

\begin{tabular}{|c|c|c|c|c|}
\hline Author/Year & Sample & Variables Employed & Methodology & Outcomes \\
\hline Kumar (2013) & $\begin{array}{l}\text { Guyana, } 1982 \\
\text { to } 2010 \text {. }\end{array}$ & $\begin{array}{l}\text { RealGDP, remittances/GDP, } \\
\text { ODA/GDP, M2/GDP }\end{array}$ & $\begin{array}{l}\text { ARDL bound } \\
\text { Test. }\end{array}$ & $\begin{array}{l}\text { Positive and long run } \\
\text { effect of remittances } \\
\text { on growth }\end{array}$ \\
\hline $\begin{array}{l}\text { Kumar and } \\
\text { Stanvermann } \\
\text { (2014) }\end{array}$ & $\begin{array}{l}\text { Kenya, } 1978 \\
\text { to } 2010 .\end{array}$ & $\begin{array}{l}\text { Tourism, remittances/GDP } \\
\text { and real GDP }\end{array}$ & $\begin{array}{l}\text { Bound Test } \\
\text { approach }\end{array}$ & $\begin{array}{l}\text { Positive effects of } \\
\text { remittances on growth }\end{array}$ \\
\hline $\begin{array}{l}\text { Kumar and } \\
\text { Stanvermann } \\
\text { (2014) }\end{array}$ & $\begin{array}{l}\text { Lithuania, } 1980 \\
\text { to } 2012\end{array}$ & $\begin{array}{l}\text { Real GDP, remittances/GDP } \\
\text { and M2/GDP }\end{array}$ & ARDL & $\begin{array}{l}\text { Positive effects of } \\
\text { remittances on growth }\end{array}$ \\
\hline $\begin{array}{l}\text { Kumar and } \\
\text { Stanvermann } \\
\text { (2014) }\end{array}$ & $\begin{array}{l}\text { Bangladesh, } \\
1979 \text { to } 2012\end{array}$ & $\begin{array}{l}\text { Real GDP, remittances/GDP } \\
\text { and M2/GDP }\end{array}$ & $\begin{array}{l}\text { ARDL Bound } \\
\text { procedure }\end{array}$ & $\begin{array}{l}\text { Positive effects of } \\
\text { remittances on growth }\end{array}$ \\
\hline $\begin{array}{l}\text { Imai et al. } \\
\text { (2014) }\end{array}$ & $\begin{array}{l}24 \text { Asia and pacific } \\
\text { countries, } 1980 \\
\text { to } 2009 .\end{array}$ & $\begin{array}{l}\text { Real GDP per capita, } \\
\text { remittance/GDP, M2/GDP, } \\
\text { Volatility of remittance and } \\
\text { FDl. }\end{array}$ & $\begin{array}{l}\text { Panel } 2 \text { stage } \\
\text { Least Square. }\end{array}$ & $\begin{array}{l}\text { Positive effects of } \\
\text { remittances on growth }\end{array}$ \\
\hline $\begin{array}{l}\text { Sarker and } \\
\text { Datta (2014) }\end{array}$ & $\begin{array}{l}\text { Bangladesh, } \\
1975 \text { to } 2011\end{array}$ & $\begin{array}{l}\text { GDP, remittances/GDP, } \\
\mathrm{M} 2 / \mathrm{GDP} \text { and other } \\
\text { control variables }\end{array}$ & $\begin{array}{l}\text { ARDL and } \\
\text { Causality }\end{array}$ & $\begin{array}{l}\text { No relationship exists } \\
\text { between remittances } \\
\text { and GDP. }\end{array}$ \\
\hline $\begin{array}{l}\text { Blouchoutzi } \\
\text { and Nikas } \\
(2014)\end{array}$ & $\begin{array}{l}\text { Moldova and } \\
\text { Albania, } 1990 \\
\text { to } 2010 .\end{array}$ & $\begin{array}{l}\text { Remittance/GDP, } \\
\text { consumption, GDP, } \\
\text { and import. }\end{array}$ & OLS & $\begin{array}{l}\text { Remittances promote } \\
\text { growth in both } \\
\text { countries. }\end{array}$ \\
\hline $\begin{array}{l}\text { Feeny } \\
\text { et al. (2014) }\end{array}$ & $\begin{array}{l}136 \text { states } \\
\text { including } 25 \text { SIDS, } \\
1971 \text { to } 2010 .\end{array}$ & $\begin{array}{l}\text { GDP per capita, remittance/ } \\
\text { GDP and other control } \\
\text { variables }\end{array}$ & GMM Estimates & $\begin{array}{l}\text { Positive effects of } \\
\text { remittances for SIDS } \\
\text { countries. }\end{array}$ \\
\hline Sibindi (2014) & $\begin{array}{l}\text { Lesotho, } 1975 \\
\text { to } 2010 \text {. }\end{array}$ & $\begin{array}{l}\text { Remittances/GDP, } \\
\text { M2/GDP and real GDP. }\end{array}$ & $\begin{array}{l}\text { VECM and } \\
\text { Granger } \\
\text { causality. }\end{array}$ & $\begin{array}{l}\text { Causality running from } \\
\text { remittances to growth. }\end{array}$ \\
\hline $\begin{array}{l}\text { Adarkwa } \\
\text { (2015) }\end{array}$ & $\begin{array}{l}\text { Cameroon, Cape } \\
\text { Verde, Nigeria and } \\
\text { Senegal, } 2000 \\
\text { to } 2010 .\end{array}$ & $\begin{array}{l}\text { GDP per capita, remittance } \\
\text { inflow and outflow }\end{array}$ & OLS & $\begin{array}{l}\text { Positive effects of } \\
\text { remittances on growth } \\
\text { in Nigeria and Senegal } \\
\text { only. }\end{array}$ \\
\hline $\begin{array}{l}\text { Coulibaly } \\
(2015)\end{array}$ & $\begin{array}{l}19 \text { sub-Saharan } \\
\text { African countries. } \\
1980 \text { to } 2010 .\end{array}$ & $\begin{array}{l}\text { GDP per capita, remittances, } \\
\text { liquidity liability and FDI }\end{array}$ & $\begin{array}{l}\text { Panel Granger } \\
\text { causality test }\end{array}$ & $\begin{array}{l}\text { No evidence of causal } \\
\text { relationship in SSA }\end{array}$ \\
\hline $\begin{array}{l}\text { Sobiech } \\
\text { (2015) }\end{array}$ & $\begin{array}{l}54 \text { Developing } \\
\text { countries, } 1970 \\
\text { to } 2010 .\end{array}$ & $\begin{array}{l}\text { Remittances/GDP, M2/GDP, } \\
\text { Private credit/GDP and GDP } \\
\text { per capita }\end{array}$ & $\begin{array}{l}\text { GMM Panel } \\
\text { Analysis. }\end{array}$ & $\begin{array}{l}\text { Negative effects of } \\
\text { remittances on growth }\end{array}$ \\
\hline $\begin{array}{l}\text { Karikari et al. } \\
(2016)\end{array}$ & $\begin{array}{l}50 \text { developing } \\
\text { countries, } 1990 \\
\text { to } 2011\end{array}$ & $\begin{array}{l}\text { Remittances/GDP, M2/GDP, } \\
\text { Private credit/GDP, FDI and } \\
\text { GDP per capita }\end{array}$ & $\begin{array}{l}\text { Panel VECM } \\
\text { causality } \\
\text { techniques. }\end{array}$ & $\begin{array}{l}\text { Remittances promotes } \\
\text { financial development. }\end{array}$ \\
\hline
\end{tabular}

Source: compiled by authors

Following Eq. (3) and previous studies such as Freund and Spatafora (2008) and Guiliano and Ruiz (2009) that remittances from migrants are spent on productive investment and capital stock in most cases, then Eq.(7) can be written as:

$$
y=\text { Aremmit }^{\alpha}
$$

Log linearizing Eq. (8) leads to:

$$
y=A+\text { aremmit }
$$

Introducing financial development and the other control variables employed gives: 


$$
y=A+\alpha_{1} \text { remmit }+\alpha_{2} \text { find }+\alpha_{3} \text { top }+\alpha_{4} \inf +\alpha_{5} \text { pop }+\alpha_{6} f d i
$$

In Eq.(10), $y$ implies log of output per labour, find implies financial development and this study adopts broad money supply to GDP as opposed to private sector credits to GDP following many previous studies such as Chami et al. (2003), Goschin (2013), Meyer and Shera (2013), Akonji and Wakili (2013), Kumar and Vu (2014), and Sobiech (2015) among others that have used broad money supply. The broad money is the sum of currency outside banks, demand deposits, savings deposits, time deposits and foreign currency deposits in a country. Apart from the use of broad money supply to GDP mostly by past studies as a measure of financial development, the fact that the composition of broad money to GDP is larger than private sector credits to GDP informs the choice of it over private sector credit to GDP. Also, top means trade openness, infimplies inflation rate, pop indicates population growth and $f d i$ means foreign direct investment while $\alpha_{1}, \alpha_{2}, \alpha_{3}, \alpha_{4}, \alpha_{5}$ and $\alpha_{6}$ represent their coefficients. Trade openness captures the extent of outward or inward orientation of the selected countries in terms of their trading activities. For each country, the ratio of trade to GDP of each country is used as the measure of trade openness. This measure has increased for most of the selected countries due to globalization and trade liberalization policy. Inflation is also used to account for the purchasing power of the individual country's currency, while population growth is included to capture the change in the number of people residing in each country. Finally foreign direct investment is a key determinant of growth in the selected countries. Re-specifying Eq.(10) in a panel data and econometric form, we have:

$$
y_{i t}=A+\alpha_{1} \text { remmit }_{i t}+\alpha_{2} \text { find }_{i t}+\alpha_{3} \text { top }_{i t}+\alpha_{4} \text { inf }_{i t}+\alpha_{5} \text { pop }_{i t}+\alpha_{6} f d i+\eta_{i}+\varepsilon_{i t}
$$

Where $A$ is the constant term, $\eta_{i}$ is an unobserved country-specific effect and $\varepsilon_{i t}$ is the error term while the variables remain as before.

\section{Methodology}

This paper adopts PMG/MG-ARDL method of estimations. Pesaran et al. (1999) proposed the PMG estimator associated with pooling and averaging of the coefficients over the cross sectional units. The MG, on the other hand, involves estimating each units separately and averaging the estimated coefficient over the cross sectional units (Pesaran and Shin, 1995). The ARDL model is employed because of its adequacy to our data set. First, it can accommodate mixture of stationarity of variables such as $\mathrm{I}(0)$ and I(1) and not I(2) like this study. It is also suitable for studies with small sample size. This study contains 20 cross sections and 16 year time series, which are relatively small for most panel studies but can be taken care of in ARDL models. Finally, it captures the dynamics of variable of interest in both the short run and the long run. Therefore, both the PMG and the MG estimations are carried out in this study. Eq. (11) can be written in panel ARDL form of Pesaran and Smith (1999) as: 


$$
\begin{aligned}
\Delta y_{i t}=A & +\phi y_{i t-1}+\alpha_{i} \sum_{i=1}^{\rho} \Delta y_{i t-i}+\pi_{i} \sum_{i=1}^{\rho} \Delta r e m m i t_{i t-i}+\omega_{i} \sum_{i=1}^{\rho} \Delta f i n d_{i t-i}+\psi_{i} \sum_{i=1}^{\rho} \Delta t o p_{i t-i} \\
& +v_{i} \sum_{i=1}^{\rho} \Delta \inf _{i t-i}+\kappa_{i} \sum_{i=1}^{\rho} f d i_{i t-i}+\theta_{i} \sum_{i=1}^{\rho} \Delta p o p_{i t-i}+\lambda_{i} \sum_{i=1}^{\rho} \Delta r e m m i t \text { find }_{i t-i}+\beta_{1} y_{i t-1} \\
& +\beta_{2} \text { remmit }_{i t-1}+\beta_{3} \text { find }_{i t-1}+\beta_{4} \text { top }_{i t-1}+\beta_{5} \text { inf }_{i t-1}+\beta_{6} \text { pop }_{i t-1}+\beta_{7} \text { fdi }_{i t-1} \\
& +\beta_{8} \text { remmit find }_{i t-1}+\eta_{i}+\varepsilon_{i t}
\end{aligned}
$$

Where $\phi$ is the coefficient of the past lagged value of the dependent variable, $\alpha_{i}$, $\pi_{i}, \omega_{i}, \psi_{i}, v_{i}, \kappa_{i}, \theta_{i}$ and $\lambda_{i}$ are the short run coefficients while $\beta_{1}$ to $\beta_{8}$ indicate the long run coefficients with remmit_find $d_{i t-i}$ and remmit_find ${ }_{i t-1}$ being the short run and the long run interactive effects of remittances and financial development. On the other hand, the MG estimator can be written following Pesaran and Shin (1995) as:

$$
M G=N^{-1} \sum_{i=1}^{N} \overline{\beta_{i}}
$$

Where MG and $\beta_{i}$ in Eq.(13) imply mean group and the coefficient estimates.

\section{Data sources and measurement}

This study sampled 20 sub-Sahara African countries for the period of 2000 to 2015. Countries were sampled from West Africa, South Africa and East Africa. The countries from West Africa are Nigeria, Senegal, Mali, Benin, Burkina Faso, Cameroon, Cape Verde, Ghana, Guinea Bissau, Togo, Niger and Cote d'Ivoire. Countries such as South Africa, Botswana, Namibia and Lesotho are from Southern Africa, while Kenya, Tanzania, Rwanda and Seychelles are from East Africa. The choice of these countries is based on the evidence of their high remittances received over the selected period. Nigeria, Senegal and Mali have the highest absolute value of received remittances between 2000 and 2015 (World Development Indicators, 2015; 2017). The selection of the study period, 2000 to 2015 , is based on the unprecedented increase in the number of emigrants and remittances received during the period. It was documented that 4.65 million migrants were recorded annually between 2000 and 2015 compared to 2.0 million migrants from 1990 to 2000 (International Migration Report, 2015). Between 2000 and 2013, Lesotho recorded an average annual remittance of 41.3 as a percentage of GDP (World Development Indicators, 2015). This is undoubtedly the highest in the whole of Sub-Sahara African countries. The remaining 16 countries are selected based on common data availability. Variables such as trade openness, inflation rate, population growth, broad money supply and FDI as percentage of GDP that are standard in the growth literature and are included as explanatory variables. The definition and measurement of the variables used in the analysis are presented in Table 3. It is worthy of note that variables like remittances and money supply are scaled by the GDP to account for the relative economic differences in the selected countries. As regards the a priori from both theoretical and empirical point of view, remittances have been found to either have positive or negative effects on growth. Studies such as Chami et al. (2003), Karagoz (2009) and Kumar (2012) found negative effects of remittances on growth. Their results suggest that remittances lead to moral hazard which discourages 
people at home to work because of the constant flow of remittances receipt. However, studies like Faini (2005), Azam and Khan (2011), Kumar and Vu (2014) and Karikari et al. (2016) found positive effects of remittances on growth through the investment of remittances received on productive venture. Financial development is expected to impact positively on growth as developed financial market affects the economy positively. A priori, trade openness is expected to impact positively or negatively on economic growth of the selected countries when countries have little to contribute and benefit in the global market. Lastly, population growth and inflation rate are expected to negatively affect economic growth. Finally, in as much as FDI can promote domestic growth through technology transfer, it can also crowd out the domestic investors through stiff competition.

\section{Descriptive statistics and correlation matrix}

It is imperative to check the descriptive statistics before analyzing the data series in order to observe the variability and distribution of the variables as shown in Table 4 . After which Table 5 also shows the correlation matrix of the variables. Table 4, shows the measures of central tendency, mean and median that give the estimates of the centre of the distribution. It is evident that on average, GDP per labour, remittances per GDP, broad money supply as a percentage of GDP and trade openness in percentage in the selected African countries are US $\$ 1957.11$ billion, US $\$ 995.43$ billion, 35.33\% and $76.50 \%$ respectively. The average GDP per labour is relative low in Africa compared to the Asia and the Middle East. The average value of money supply as a percentage of GDP is low while that of remittances per GDP and trade openness as a percentage of GDP are high. The average values of FDI as a percentage of GDP with a value of $3.45 \%$ is low for the sample country as a whole. The average inflation and population growth within these period is low with a value of $5.44 \%$ and $2.36 \%$. It can be observed that the mean and median of inflation and population growth are very close, which denotes a nearly symmetric distribution and the existence of low variability. The highest GDP per labour recorded is US $\$ 15695.90$ billion while the minimum is US $\$ 160.22$ billion. The maximum remittances per GDP received in the SSA countries

Table 3 Variable Description, Measurement and Sources

\begin{tabular}{|c|c|c|c|c|}
\hline Variable & Definition & Unit of Measurement & Expected Sign & Source \\
\hline y & Gross Domestic Product per labour & $\frac{G D P}{\text { labour }}$ & & WDI 2017 \\
\hline remmit & Personal remittances & $\begin{array}{l}\text { Personal remittances received } \\
\text { by each country/GDP in \% }\end{array}$ & $\begin{array}{l}\text { Positive/ } \\
\text { Negative }\end{array}$ & WDI 2017 \\
\hline fdi & Foreign direct investment & FDI/GDP in $\%$ of each country & $\begin{array}{l}\text { Positive/ } \\
\text { Negative }\end{array}$ & WDI 2017 \\
\hline find & $\begin{array}{l}\text { Broad Money Supply i.e. bank } \\
\text { deposit and other deposits } \\
\text { including notes and coin }\end{array}$ & $\mathrm{M} 2 / \mathrm{GDP}$ in $\%$ of each country & Positive & WDI 2017 \\
\hline top & Trade Openness & $\frac{\text { Export+ Import* }}{G D P} 100$ & Positive & WDI 2017 \\
\hline $\begin{array}{l}\inf \\
\text { pop }\end{array}$ & $\begin{array}{l}\text { Inflation } \\
\text { Population Growth }\end{array}$ & $\begin{array}{l}\frac{C P l_{t}-C P I_{t-1}}{C P I_{t-1}} \text { in \% } \\
\text { Population Growth } \\
\text { (annual \%) }\end{array}$ & $\begin{array}{l}\text { Negativ } \\
\text { Negative }\end{array}$ & $\begin{array}{l}\text { WDI } 2017 \\
\text { WDI } 2017\end{array}$ \\
\hline
\end{tabular}


Table 4 Descriptive Statistics of selected variables

\begin{tabular}{llllllll}
\hline & $\mathrm{y}$ & remmit & find & top & inf & pop & fdi \\
\hline Mean & 1957.11 & 995.43 & 35.33 & 76.50 & 5.44 & 2.36 & 3.45 \\
Median & 806.14 & 145.87 & 28.78 & 63.74 & 4.3823 & 2.56 & 2.26 \\
Maximum & $15,695.90$ & $21,059.70$ & 110.77 & 225.02 & 36.96 & 5.60 & 54.06 \\
Minimum & 160.22 & 1.80 & 8.16 & 21.45 & -9.62 & -2.63 & -0.90 \\
Std. Dev. & 2722.35 & 3532.29 & 19.74 & 40.05 & 5.78 & 0.87 & 4.51 \\
Skewness & 2.48 & 4.96 & 1.46 & 1.61 & 2.12 & -1.07 & 5.62 \\
Kurtosis & 9.49 & 26.37 & 4.77 & 5.33 & 10.39 & 7.07 & 55.75 \\
J-Bera & 868.69 & 8385.52 & 152.05 & 205.87 & 943.97 & 276.13 & $36,720.41$ \\
Prob. & 0.00 & 0.00 & 0.00 & 0.00 & 0.00 & 0.00 & 0.00 \\
Obs. & 320 & 320 & 320 & 320 & 320 & 320 & 320 \\
\hline
\end{tabular}

y, remmit, find, top, inf, pop and fdi represent economic growth, remittances, broad money supply, trade, openness, inflation, population growth and foreign direct investment respectively

is US\$15695.90 billion as against the minimum value of US $\$ 160.22$ billion. The maximum broad money supply is $110.77 \%$ with the minimum of $8.16 \%$. GDP per capital, remittance, trade openness, broad money supply and inflation are positively skewed while only population growth is negatively skewed. Lastly, the Jarque-Bera statistic exceeds $0.05 \%$ level of significance for all the series. This is an indication that the null hypothesis of normal distribution for the series is rejected at this significance level. The absence of normal distribution may be attributed to cross-sectional and heterogeneous nature of the data used in this study. Such heterogeneities are usually corrected during estimation in panel data analysis. Furthermore, from Table 5, financial development, trade openness, inflation rate and financial development show positive relationships to the GDP per labour while negative relationships are found for both remittances and population growth. Only financial development and population growth are found to be above 0.50, which signify strong linear relationships with GDP per labour. There is a weak and negative correlation value of 0.19 between GDP per labour and remittances. A strong and positive correlation value of 0.71 between financial development and GDP per labour, while a negative correlation value of 0.53 is found between population growth and GDP per labour. Finally, a weak positive correlation value of 0.09 is found for inflation, while moderate positive correlation values of 0.39 and 0.31 are found for trade openness and foreign direct investment respectively.

Table 5 Correlation Matrix of the selected variables

\begin{tabular}{llllllll}
\hline & $y$ & remmit & find & top & inf & pop & fdi \\
\hline$y$ & 1 & & & & & \\
remmit & -0.19 & 1 & & & & \\
find & 0.71 & 0.01 & 1 & & & \\
top & 0.38 & 0.49 & 0.51 & 1 & & \\
inf & 0.09 & -0.02 & -0.01 & 0.16 & 1 & 1 \\
pop & -0.53 & -0.3 & -0.59 & -0.64 & -0.11 & & \\
fdi & 0.31 & -0.01 & 0.31 & 0.49 & 0.12 & -0.24 & 1 \\
\hline
\end{tabular}

Calculated by authors 


\section{Panel unit root tests}

Before analyzing the inferential estimation among the variables, there is need to check the time series properties of the variables. This was done in order to correctly apply the panel ARDL which is suitable for purely $\mathrm{I}(0)$ and purely $\mathrm{I}(1)$ variables and not for $\mathrm{I}(2)$ variables (Pesaran, Shin and Smith, 2001). In other words, panel unit root tests such as Levin, Lin and Chu (2002) (LLC), Im, Pesaran and Shin (2003) (IPS), Augmented Dickey Fuller (ADF, 1979) and Phillip-Perron (PP, 1988) tests were performed. Table 6 shows that GDP, trade openness, inflation and foreign direct investment are stationary at levels, meaning that they are I(0) variables using LLC, IPS, ADF and PP panel unit root tests. Although, remittance is stationary using LLC and PP but not for IPS and $\mathrm{ADF}$ at level form, it is therefore differenced once to assume a first difference stationary. The same applies to financial development variable. As for population growth series, it is stationary at levels for ADF and PP but difference once to have it stationary at first difference. After first difference, it is then stationary for three out of the four panel tests. Therefore, variables such as remittances, financial development and population growth follow I(1) process, while GDP, trade openness, inflation and foreign direct investment are I(0). This unit root results imply that the variables are of mixed stationary i.e. $\mathrm{I}(0)$ and $\mathrm{I}(1)$ processes which fit the PMG/ARDL model.

\section{Panel cointegration tests}

After the confirmation of mixed stationary status of the variables in the panel unit root test, we examined the co-integrating relationship among the variables using both Pedroni (1999) and Kao (1999) panel co-integration tests. Pedroni (1999) checks the properties of residual-based tests for the null hypothesis of no co-integration for dynamic panels in which both the short-run dynamics and the long-run slope coefficients are permitted to be heterogeneous across individual members of the panel. Pedroni test considers both pooled within dimension tests and group mean between dimension tests with individual intercept in the test. As shown in Tables 7 and 8, the Kao residual panel co-integration test shows that, the null hypothesis of no co-integration is rejected at $5 \%$ level of significance while the Pedroni panel co-integration result reveals that 6 out of

Table 6 Panel Unit Root Results with Individual Intercept

\begin{tabular}{lllllllllll}
\hline Variable & Level & LLC & $P-v$ & IPS & $P-v$ & ADF & $P-v$ & $P P$ & $P-v$ & Status \\
\hline y & 0 & -7.09 & $0.00^{* * *}$ & -2.15 & $0.02^{* *}$ & 57.28 & $0.04^{* *}$ & 67.37 & $0.00^{* * *}$ & $I(0)$ \\
remmit & 0 & -5.96 & $0.00^{* * *}$ & -0.82 & 0.2 & 52.07 & 0.1 & 74.7 & $0.00^{* * *}$ & \\
& 1 & -10.7 & $0.00^{* * *}$ & -8.18 & $0.00^{* * *}$ & 135.1 & $0.00^{* * *}$ & 147.1 & $0.00^{* * *}$ & $I(1)$ \\
find & 0 & -2.89 & $0.00^{* * *}$ & 0.08 & 0.53 & 50.36 & 0.12 & 47.47 & 0.19 & \\
& 1 & -13.5 & $0.00^{* * *}$ & -11.84 & $0.00^{* * *}$ & 191.8 & $0.00^{* * *}$ & 241.9 & $0.00^{* * *}$ & $I(1)$ \\
top & 0 & -3.48 & $0.00^{* * *}$ & -1.56 & $0.06^{*}$ & 55.39 & $0.05^{*}$ & 52.61 & $0.09^{*}$ & $\mid(0)$ \\
inf & 0 & -11.3 & $0.00^{* * *}$ & -8.57 & $0.00^{* * *}$ & 146.3 & $0.00^{* * *}$ & 176.8 & $0.00^{* * *}$ & $I(0)$ \\
pop & 0 & 27.45 & 1.00 & 2.72 & 0.1 & 98.39 & $0.00^{* * *}$ & 69.68 & $0.00^{* * *}$ & \\
& 1 & 96.77 & $0.00^{* * *}$ & -3.92 & $0.00^{* * *}$ & 107.5 & $0.00^{* * *}$ & 87.02 & $0.00^{* * *}$ & $I(1)$ \\
fdi & 0 & -3.78 & $0.00^{* * *}$ & -3.46 & $0.00^{* * *}$ & 78.56 & $0.00^{* * *}$ & 104.99 & $0.00^{* * *}$ & $I(0)$ \\
\hline
\end{tabular}

***, **, and * indicate significance at $0.01 \%, 0.05 \%$, and $0.10 \%$; P-v indicates probability value. All the variables are expressed in log form except inflation and population growth that are already in rates 
Table 7 Kao Residual Panel Cointegration result

\begin{tabular}{lcc}
\hline Test & t-statistics & Prob. \\
\hline Kao cointegration test & -1.8710 & $0.03^{\mathrm{a}}$ \\
\hline${ }^{\mathrm{a}}$ Denotes statistical significance at 5\% level & &
\end{tabular}

the 11 of the Pedroni statistics significantly reject the null hypothesis of no co-integration.

\section{Cross sectional dependence}

There is the need to first of all perform the tests of cross sectional dependence on our data to ensure that the cross section in the panel data analysis are independent for consistent coefficient estimates (Pesaran, 2004). We adopt the cross section dependence (CD) that supports larger cross section $(N)$ and smaller time series $(T)$ like this study with $N=20>T=16$. The cross sectional dependence test in Table 9 cannot be rejected at $0.01 \%$ level of significance. This implies that there is presence of cross sectional dependence in our data. Thus, in order to obtain unbiased estimates of our analysis, we conducted a diagnostic test by applying panel unit root tests in the presence of cross sectional dependence on the residual estimates (Pesaran, 2007). The outcome of the panel unit root tests on the residual, as presented in Table 12, shows that the residual is stationary at level i.e. it follows $\mathrm{I}(0)$ process and the stationarity validates the estimates of the MG and PMG ARDL panel results.

\section{Empirical results and discussion}

The results of short and the long run effects of remittances and financial development on economic growth are presented in Tables 10 and 11 separately for the PMG and the MG method. The optimal lag length of panel ARDL $(1,1,1,1,1,1,1)$ is chosen for both the PMG and MG estimations following the Schwarz information criterion (SIC). The short and the long run results are similar for both the PMG and the MG estimations in terms of the relationship between the dependent and the independent variables. In the short-run, the coefficients of remittances of 0.7914 and 0.8305 are positive and statistically significant at $0.01 \%$ level of significance for both the PMG and the MG estimates respectively. These suggest that in the short run, $1 \%$ increase in remittance inflows to the selected African countries

Table 8 Pedroni Cointegration Test

\begin{tabular}{lllll}
\hline Tests & Statistic & Prob. & Statistic & Prob. \\
\hline Panel v-Statistic & -1.1302 & 0.87 & -0.7530 & 0.77 \\
Panel rho-Statistic & -4.5085 & $0.00^{\mathrm{a}}$ & -4.4766 & $0.00^{\mathrm{a}}$ \\
Panel PP-Statistic & -2.2612 & $0.01^{\mathrm{b}}$ & -2.6919 & $0.00^{\mathrm{a}}$ \\
Panel ADF-Stat & -0.1490 & 0.44 & -1.2244 & 0.11 \\
Between-Dimension & & & & \\
Panel rho-Statistic & -5.1589 & $0.00^{\mathrm{a}}$ & & \\
Panel PP-Statistic & -1.8037 & 0.13 & & \\
Panel ADF-Stat & -3.0452 & $0.00^{\mathrm{a}}$ & & \\
\hline
\end{tabular}

${ }^{\mathrm{a}}$ and ${ }^{\mathrm{b}}$ signifies $1 \%$ and $5 \%$ significance level 
Table 9 Cross sectional dependence tests

\begin{tabular}{lll}
\hline Tests & Statistic & Prob \\
\hline Breusch-Pagan LM & $813.82^{\mathrm{a}}$ & 0.00 \\
Pesaran Scaled LM & $30.97^{\mathrm{a}}$ & 0.00 \\
Pesaran CD & $10.68^{\mathrm{a}}$ & 0.00 \\
\hline
\end{tabular}

${ }^{a}$ indicates $0.01 \%$ level of significance

would lead to $0.791 \%$ or $0.831 \%$ increase in economic growth. In other words, the short-run impact of remittances on economic growth is positive and statistically significant, indicating that remittances contribute positively to economic growth of the SSA countries in the short-run for both the PMG and the MG estimates. This finding is consistent with the claim of Nyamongo et al. (2012), Adarkwa (2015) and Karikari et al. (2016) for Africa that remittances appear to be one of the most significant sources of capital for economic development. In the same manner, financial development has positive and significant effect on economic growth in the short-run for the SSA countries at $0.01 \%$ significance level for both the PMG and MG estimates. These results show that $1 \%$ increase in the financial development would increase economic growth by $0.007 \%$ for the PMG method and $0.003 \%$ for MG. The degree of trade openness however, has a negative and insignificant relationship with economic growth in the short run for both the PMG and MG estimates. The coefficients value of -0.010 and -0.0010 infer that $1 \%$ increase in trade openness would reduce economic growth either by $0.010 \%$ or by -0.001 in the SSA countries. These results support the earlier works of Nzotta et al. (2013) and Metu and Chinedua (2015) that postulated trade openness not to have significant contribution to the economic growth of developing countries.

Table 10 The short and long run Pooled Mean Group/ARDL results

\begin{tabular}{|c|c|c|c|c|}
\hline \multicolumn{2}{|c|}{ Dependent variable: GDP } & \multicolumn{2}{|c|}{ PMG/ARDL $(1,1,1,1,1,1,1)$} & \multirow[t]{2}{*}{ Prob. } \\
\hline Variables & Coefficients & std-error & t-statistics & \\
\hline $\mathrm{d}($ remmit $(-1))$ & 0.7914 & 0.3263 & 2.4256 & $0.02^{* *}$ \\
\hline$d($ find $(-1))$ & 0.0071 & 0.0094 & 0.7567 & 0.45 \\
\hline$d(\operatorname{top}(-1))$ & -0.0100 & 0.0024 & -0.3581 & 0.72 \\
\hline$d(p o p(-1))$ & 0.0279 & 0.9953 & 2.0375 & $0.04^{* *}$ \\
\hline$d(\inf (-1))$ & 0.0100 & 0.0068 & 0.3272 & 0.74 \\
\hline$d(f d i(-1))$ & -0.0118 & 0.0115 & -1.0284 & 0.31 \\
\hline d (remmit_find $(-1))$ & -0.0357 & 0.0222 & -1.6081 & 0.11 \\
\hline $\operatorname{ecm}(-1)$ & -0.1352 & 0.1039 & -1.3014 & 0.19 \\
\hline remmit & 0.1567 & 0.0237 & 6.6246 & $0.00^{* * *}$ \\
\hline find & 0.0725 & 0.0024 & 30.3592 & $0.00^{* * *}$ \\
\hline top & 0.0100 & 0.0008 & 10.2832 & 0.31 \\
\hline pop & 0.2296 & 0.0382 & 6.0138 & $0.00^{* * *}$ \\
\hline $\inf$ & 0.0084 & 0.0021 & 13.7667 & 0.15 \\
\hline fdi & -0.0883 & 0.0016 & -5.1179 & $0.00^{* * *}$ \\
\hline remmit_find & -0.0038 & 0.0003 & -10.8270 & $0.00^{* * *}$ \\
\hline
\end{tabular}

*** and ** signify $0.01 \%$ and $0.05 \%$ level of significance 
Table 11 The short and long run Mean Group/ARDL results

\begin{tabular}{|c|c|c|c|c|}
\hline \multicolumn{2}{|c|}{ Dependent variable: GDP } & \multicolumn{2}{|c|}{ MG/ARDL $(1,1,1,1,1,1,1)$} & \multirow[t]{2}{*}{ Prob. } \\
\hline variables & coefficients & std-error & t-statistics & \\
\hline $\mathrm{d}($ remmit $(-1))$ & 0.8305 & 0.3263 & 2.4256 & $0.00^{* * *}$ \\
\hline$d($ find $(-1))$ & 0.0033 & 0.0094 & 0.7567 & $0.00^{* * *}$ \\
\hline$d(\operatorname{top}(-1))$ & -0.0010 & 0.0024 & -0.3581 & 0.72 \\
\hline$d(p o p(-1))$ & 0.0135 & 0.9953 & 2.0375 & $0.06^{*}$ \\
\hline$d(\inf (-1))$ & 0.0311 & 0.0068 & 0.3272 & 0.19 \\
\hline$d(f d i(-1))$ & 0.0844 & 0.0115 & -1.0284 & $0.00^{* * *}$ \\
\hline$d$ (remmit_find $(-1))$ & -0.0357 & 0.0222 & -1.6081 & $0.00^{* * *}$ \\
\hline $\operatorname{ecm}(-1)$ & -0.1604 & 0.1039 & -1.3014 & 0.00 \\
\hline remmit & 0.0861 & 0.0215 & 4.0030 & $0.00^{* * *}$ \\
\hline find & 0.0971 & 6.6292 & 4.5160 & $0.00^{* * *}$ \\
\hline top & 0.4663 & 4.3070 & 1.7335 & $0.08^{*}$ \\
\hline pop & 0.5416 & 0.0382 & 6.0138 & $0.06^{*}$ \\
\hline $\inf$ & -0.0045 & 9.9230 & -2.2377 & $0.04^{* *}$ \\
\hline fdi & -0.0400 & 0.0016 & -5.1179 & $0.00^{* * *}$ \\
\hline remmit_find & -0.0021 & 0.0003 & -10.827 & $0.00^{* * *}$ \\
\hline
\end{tabular}

***,** and ${ }^{*}$ signify $0.01 \%, 0.05 \%$ and $0.10 \%$ level of significance

Population growth with coefficient values of 0.0279 and 0.0135 is found to have positive and significant effects on growth at $0.05 \%$ significance level for both the PMG and MG estimates. This implies $1 \%$ increase in population growth would increase significantly economic growth by $0.028 \%$ or by $0.014 \%$. On the other hand, inflation rate and FDI are found to be insignificantly related to economic growth with coefficient values of 0.010 and -0.0118 respectively for the PMG estimate. The MG results however, show FDI to have positive and significant effect on economic growth at $0.01 \%$ significance level while inflation has positive but insignificant effect on economic growth. The Error Correction term (ECT) indicates the speed of adjustment from short run disequilibrium to long run equilibrium. The ECT parameter coefficient is expected to be negative and significant. It is negative and significant only for the MG estimate. The coefficient of the ECT or the speed of adjustment towards equilibrium for the MG estimate is -0.1604 , indicating that the deviation of variables from the short to the long run equilibrium is significantly adjusted and corrected by $0.160 \%$ annually for the SSA countries.

The next is to discuss the long run results. As presented in Tables 11 and 12, it can be observed that, in the long run, remittances are also positive and statistically

Table 12 Residual panel unit root tests

\begin{tabular}{llll}
\hline Unit root tests & Statistics & Prob & cross section \\
\hline Levin, Lin and Chu & $-4.4742^{\mathrm{a}}$ & 0.00 & 20 \\
Im, Pesaran and Shin W-stat & $-6.1361^{\mathrm{a}}$ & 0.00 & 20 \\
ADF-Fisher Chi-square & $115.22^{\mathrm{a}}$ & 0.00 & 20 \\
PP-Fisher Chi-square & $220.55^{\mathrm{a}}$ & 0.00 & 20 \\
\hline
\end{tabular}

${ }^{\mathrm{a}}$ indicates significance at $0.01 \%$ 
significant at $0.01 \%$ significance level for both the PMG and MG estimates. The coefficient values of 0.1567 and 0.0861 indicate that $1 \%$ increase in remittances would lead to either 0.157 or $0.086 \%$ increase in economic growth for SSA countries. This finding aligns with the postulation of the structural migration optimists who see remittances as a medium to increase development in the migrants' countries. The result is affirmative to the opinion of one of the migration optimists, Kindleberger (1965) who argues that remittances impact on growth through increase in household income, consumption, investment and employment generation. Among several earlier studies which have obtained the similar result are Nyamongo et al. (2012) for SSA, Akonji and Wakili (2013) for Nigeria, Kumar and Vu (2014) for Kenya and Adarkwa (2015) for SSA. They all discovered positive relationship between remittances and economic growth for different countries at different period. We therefore conclude that in the long run, inflow of remittances has positive and significant impact on the economic growth of the sampled countries within the study period.

With respect to the effects of financial development on economic growth, the long run results of both the PMG and MG also support the short run result, that financial development has positive and significant effect on economic growth in the selected African countries at $0.01 \%$ significance level. The result reveals that $1 \%$ increase in financial development would lead to increase in economic growth by 0.073 or by $0.097 \%$ in the long run. These outcome corroborate the supply leading hypothesis of Bagehot (1873), Schumpeter (1911), Mckinnon and Shaw (1973) which observed that well organized financial system could surely spur innovation and future real growth with respect to identification and funding of productive investment. Similar studies which confirmed this result are Dickson and Eshenake (2013), Abidemi and Bidemi (2014), Praise et al. (2014) and Kibet and Agbelenko (2015) who observed a positive and significant relationship between financial development and economic growth in West African Economic and Monetary Union (WAEMU). Therefore, this study also concludes that financial development positively and significantly affects the economic growth of the selected SSA countries in the long run over. Furthermore, the coefficients of trade openness are positive both only significant for MG estimate at 0.10 significance level. The coefficient value of 0.4663 implies that $1 \%$ increase in trade openness would lead to $0.466 \%$ increase in economic growth in the long run with MG estimate. This outcome supports the findings of Ndikumana and Lutz (2007) and Abidal and Zghidi (2014) that trade openness had significant and positive impact on economic growth in 3 countries of North Africa (Tunisia, Morocco and Egypt). On the contrary, population growth exhibits positive and significant relationship with economic growth at $0.01 \%$ significance level only for the PMG estimate with a coefficient value of 0.2296 . This connotes that $1 \%$ increase in the growth of population would increase economic growth by $0.230 \%$ over the study period. This result is therefore in line with the findings of Mamingi and Perch (2013) which found that population growth and population density have a positive effect on growth. In addition, the results show that in the long-run, inflation is negative and statistically significant at 0.05\% significance level for MG estimate but positive and insignificant using PMG method. The coefficient value of 0.005 implies that $1 \%$ increase in inflation rate would reduce economic growth by $0.005 \%$ in the SSA countries. Lastly, FDI on the 
other hand is found to have negative effect on economic growth in the long run for both PMG and MG estimates. The result implies that 1\% increase in FDI would decrease economic growth either by 0.088 or by $0.040 \%$ significantly in the long run.

We further verify the complementary or substitutability relationship of financial development and remittances on economic growth in the SSA countries over the period of study as shown along with the individual variables in Tables 11 and 12 . This exercise is motivated from the submission of previous authors that remittances can complement financial development i.e. remittances thrive in countries with well-developed financial system (Aggarwal et al., 2011, Akonji and Wakili, 2013) while others postulated that remittances provide an alternative way to finance investment and help to overcome liquidity constraints, i.e. it acts as a substitute in countries with less-developed financial system (Giuliani and Ruiz Arranz, 2009; Fayissa and Nsiah, 2010; Sobiech, 2015).

As a result, we explore the short run interactive effects of both remittances and financial development (d (remmit_find $(-1)$ )) on economic growth for both PMG and MG estimates. We found negative interactive effects and statistically significance for MG results both in the short run and the long run at 0.01 significance level. However, we found significant negative interactive term in the long run for PMG approach at $0.01 \%$ significance level. The negative interactive effects indicate the existence of substitute relationship between remittances and financial development in the SSA countries. The results imply that remittances and financial services substitute for each other in the SSA countries to impact on growth.

\section{Granger causality test}

After establishing the existence of co-integrating relationship among remittances, financial development and economic growth variables, we then proceed to perform Granger Causality/Block Exogeneity Wald tests for causality based on Vector autoregressive (VAR) model. The existence of co-integration among remittances, financial development and economic growth confirms that there ought to be at least one existence of causal relationship. The idea of causal relationship stems from the fact that financial development such as the technological innovation of money gram, mobile transfer, mobile banking, digital payment and savings can motivate remittance inflows. In other words, the quest to make more profit by banks can create a payment system that attracts remittance flow. Financial development can equally cause economic growth and a developed economy can also create a developed financial market to meet growth demands. In terms of causal relationship between remittances and growth, inflow of remittances may lead to economic growth, at least from the optimistic point of view that remittances promote economic growth through increase in household income and investment in the home country. Similarly, availability of growth potential in the home country may create incentive for remittance inflow from abroad. Fenny et al. (2014) reported that migrants can respond to lower rates of economic growth in their home countries by remitting more to their families. In the same vein, low growth rates might also lead to higher level of emigration and therefore more remittances (Barajas et al. 2009). Also, many studies in the literature 
such as Siddique et al. (2010), Koay and Choog (2013), Akkoyunlu (2013), Sibindi (2014) and Coulibaly (2015) among others have examined causality among remittances, financial development and economic growth on different countries. The multivariate granger causality VAR model can be written as:

$$
\begin{aligned}
& y=\alpha_{1}+\alpha_{i} \sum_{i=1}^{\rho} y_{i t-i}+\beta_{i} \sum_{i=1}^{\rho} \text { remmit }_{i t-i}+\omega_{i} \sum_{i=1}^{\rho} \text { find }_{i t-i}+\varepsilon_{1 t} \\
& \text { remmit }=\alpha_{2}+\phi_{i} \sum_{i=1}^{\rho} y_{i t-i}+\pi_{i} \sum_{i=1}^{\rho} \text { remmit }_{i t-i}+\vartheta_{i} \sum_{i=1}^{\rho} \text { find }_{i t-i}+\varepsilon_{2 t} \\
& \text { find }=\alpha_{3}+\kappa_{i} \sum_{i=1}^{\rho} y_{i t-i}+\tau_{i} \sum_{i=1}^{\rho} \text { remmit }_{i t-i}+v_{i} \sum_{i=1}^{\rho} \text { find }_{i t-i}+\varepsilon_{3 t}
\end{aligned}
$$

The granger causality result, as shown in Table 13, reveals that there are unidirectional causal flows from GDP to remittances at $0.05 \%$ level of significance and from financial development to GDP at $0.01 \%$ level of significance. However, there are no causal relationships between remittances and financial development as the null hypothesis cannot be rejected. This outcome supports the findings of Motelle (2011) and Sibindi (2014) which confirmed that there is no causality running from remittances to financial development in Lesotho, a sub-Saharan African country. Our result is also in line with Coulibaly (2015) that there is evidence of causal relationship between remittances and financial development in SSA countries.

\section{Conclusion, policy implication and recommendation}

This study re-examined the relationship among remittances, financial development and economic growth in 20 selected countries in Sub-Sahara Africa. We employed both the MG and PMG/ARDL model with VAR Granger causality/block exogeneity test. After establishing cointegration among the variables, the estimated results indicated that remittances exert significant positive effects on economic growth both in the short run and the long run. In the same vein, financial development significantly increases economic growth both in the long run and in the short run. In addition, we found unidirectional causalities to run from economic growth to remittances and from financial development to economic growth. On the other hand, no causal relationship was found between remittances and financial development in the SSA countries. The absence of causality between remittances and financial development justifies the earlier result of substitute relationship between

\begin{tabular}{|c|c|c|c|c|c|c|c|}
\hline \multirow[b]{2}{*}{ Indep. Var. } & \multirow[t]{2}{*}{ Dep.Var. } & \multicolumn{2}{|l|}{$y$} & \multirow{2}{*}{$\begin{array}{l}\text { find } \\
\text { Chi-square }\end{array}$} & \multicolumn{3}{|c|}{ remmit } \\
\hline & & chi-square & $p$-val & & $p$-val & Chi-square & $p$-val \\
\hline y & & - & - & 0.7494 & 0.29 & 6.1392 & $0.04^{* *}$ \\
\hline find & & 10.6057 & $0.00^{* * *}$ & - & - & 1.4081 & 0.32 \\
\hline remmit & & 1.4462 & 0.49 & 2.472 & 0.69 & - & - \\
\hline
\end{tabular}
them. This suggests a disconnection between remittance inflow and the financial

Table 13 VAR Granger Causality/Block Exogeneity Wald Test

*** and ${ }^{* *}$ signifies 0.01 and $0.05 \%$ significance level and optimal lag length of 1 that satisfies Schwarz criterion was used. See Appendix for the Diagnostic tests of the panel VAR lag selection criteria, the panel VAR causality lag correlation and the Panel VAR lag selection stability test 
markets in SSA reflecting low financial development and remittance inflow through the informal financial markets. This may equally suggest that the number of remittance recipients that access financial services in SSA is still small compared to the volume of remittance inflow. Low penetration and concentration of banks could be hindrances in terms of far distance to the nearest financial units. This study, therefore, concludes that both remittances and financial development constitute effective sources of economic growth in SSA region, however, the interrelationship between remittance and financial development does not matter in the growth process in SSA. The findings of this study have generated important policy implications and recommendations. In the first instance, this study ascertained that remittances do promote economic growth in the SSA countries. The conclusion can be explained from the optimistic view that increase in aggregate demand would result from increase in consumption and investment of the remittance receiving families. The productive sector can then benefit from the increase in the aggregate demand through the multiplier effects. Furthermore, causality is found to run from economic growth to remittances. The implication of the causal effect is that availability of the growth potentials and investment opportunities at the home countries attract the huge flow of remittances from abroad to the SSA countries. Secondly, the study revealed that financial development is a powerful tool to improve economic growth in the SSA countries with causality running from financial development to economic growth. The policy recommendation is that improved financial services, financial instruments and the payment system are necessary for economic growth in SSA countries both in the short run and long run. The short and the long term financial policies in SSA should be focused towards improving the financial sector performance through the formulation and implementation of sound financial reforms to deepen the financial sector. There should be diversification of the banking services and increased financial inclusion such as the use of mobile banking, internet banking, automated Teller machines (ATM) and rural banking that will integrate more remittance-recipient households in SSA from the informal financial sectors into the formal financial system for inclusive growth.

\section{Appendix}

Table 14 Panel VAR Causality Lag Order Selection Criteria Endogenous variables: GDP, M2, REMMIT

\begin{tabular}{llllll}
\hline Lag & LogL & LR & FPE & AIC & SC \\
\hline 0 & -3115.317 & NA & $7.00 \mathrm{e}+09$ & 31.18317 & 31.23265 \\
1 & -2341.953 & 1515.794 & $3,354,843$. & 23.53953 & $23.73743^{\mathrm{a}}$ \\
2 & -2332.336 & 18.56149 & $3,334,429 .^{\mathrm{a}}$ & $23.53336^{\mathrm{a}}$ & 23.87968 \\
3 & -2325.718 & 12.57373 & $3,415,379$. & 23.55718 & 24.05193 \\
4 & -2319.978 & 10.73414 & $3,529,608$. & 23.58978 & 24.23295 \\
5 & -2316.007 & 7.306442 & $3,713,427$. & 23.64007 & 24.43167 \\
6 & -2303.900 & $21.91281^{a}$ & $3,602,349$. & 23.60900 & 24.54902 \\
\hline
\end{tabular}

${ }^{\mathrm{a}}$ indicates lag order selected by the criterion

$L R$ sequential modified LR test statistic (each test at $5 \%$ level)

FPE Final prediction error

AIC Akaike information criterion

SC Schwarz information criterion

HQ Hannan-Quinn information criterion 
Table 15 Panel VAR Causality Lag Correlation Test

Sample: 20002015

Included observations: 320

Correlations are asymptotically consistent approximations

\begin{tabular}{|c|c|c|c|c|}
\hline _GDP,_M2(-i) & _GDP,_M2(+i) & i & lag & lead \\
\hline||$^{* * * * * * *} \mid$ & $.||^{* * * * * * *} \mid$ & 0 & 0.7026 & 0.7026 \\
\hline$.||^{* * * * * * *} \mid$ & $.||^{* * * * * *} \mid$ & 1 & 0.6877 & 0.6626 \\
\hline||$^{* * * * * * *} \mid$ & ||$^{* * * * * *} \mid$ & 2 & 0.6679 & 0.6027 \\
\hline$.||^{* * * * * *} \mid$ & $.||^{* * * * *} \mid$ & 3 & 0.6411 & 0.5390 \\
\hline||$^{* * * * * *} \mid$ & $.||^{* * * * *} \mid$ & 4 & 0.6051 & 0.4717 \\
\hline||$^{* * * * * *} \mid$ & ||$^{* * * *} \mid$ & 5 & 0.5620 & 0.4009 \\
\hline$.\left.\right|^{* * * * *} \mid$ & $.\left.\right|^{* * *} \mid$ & 6 & 0.5103 & 0.3363 \\
\hline$.||^{* * * * *} \mid$ & $.\left.\right|^{* * *} \mid$ & 7 & 0.4655 & 0.2792 \\
\hline||$^{* * * *} \mid$ & $.\left.\right|^{* *} \mid$ & 8 & 0.4149 & 0.2289 \\
\hline||$^{* * * *} \mid$ & $\left.\right|^{* *} \mid$ & 9 & 0.3723 & 0.1783 \\
\hline$.\left.\right|^{* * *} \mid$ & $\left.\right|^{*} \mid$ & 10 & 0.3234 & 0.1383 \\
\hline.$^{* * *}$ &.$^{*}$ & 11 & 0.2697 & 0.1011 \\
\hline
\end{tabular}

Inverse Roots of AR Characteristic Polynomial

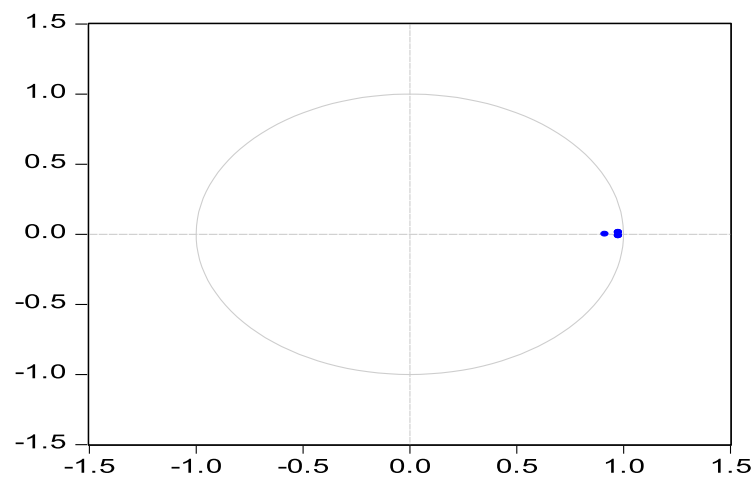

Fig. 2 Panel VAR causality Lag Selection Stability Test

\section{Abbreviations}

ARDL: Autoregressive Distributed Lag; FDI: Foreign Direct Investment; GDP: Gross Domestic Product; MG: Mean Group; ODA: Official Development Aid; PMG: Pooled Mean Group; WDI: World Development Indicator

\section{Acknowledgements}

The authors appreciate the editor and the three reviewers for their comments in making better this work a better one.

Funding

There is no funding for this work

\section{Availability of data and materials}

All the data used are available in World Development Indicator (WDI, 2017).

\section{Author's Contributions}

AQ did the write-up, collected the data and then analyzed the result as a student under the supervision of DO. DO supervised the work, read, made necessary correction and drafted the manuscript for submission. Both authors read and approved the final manuscript. 


\section{Competing interests}

There is no financial and non-financial competing interest in this work. The authors declare that they have no competing interests.

\section{Publisher's Note}

Springer Nature remains neutral with regard to jurisdictional claims in published maps and institutional affiliations.

Received: 9 November 2017 Accepted: 18 January 2019

Published online: 19 February 2019

\section{References}

Abidal Z, Zghidi N (2014) Financial development, trade openness and economic growth in North African countries. Romanian Economic J 17(53):91-120

Abidemi Ol, Bidemi AS (2014) Financial sector development and economic growth: the Nigerian experience. Sch J Bus Adm 4(55):124-131

Adarkwa MA (2015) Impact of remittances on economic growth: evidence from selected West African countries (Cameroon, Cape Verde, Nigeria and Senegal). African Human Mobility Review 1(2):178-202

Aggarwal R, Demirguc-Kunt A, Peria MSM (2011) Do remittances promote financial development. J Dev Econ 96:255-264

Akkoyunlu S (2013) Remittances and financial development: Is there a direct link? Evidence from Turkey Data, Presented by Mrs. Sule Akkoyunlu at the Conference on "Migration: Global Development, New Frontiers", 10-13 April 2013, University College London

Akonji DR, Wakili AM (2013) The impact of net migrant remittance on economic growth: evidence from Nigeria. Int J Hum Soc Sci 3(8) Alkhathlan KA (2013) The nexus between remittance outflows and growth: a study of Saudi Arabia. Econ Model 33:695-700 Azam M, Khan A (2011) Workers' remittances and economic growth: evidence from Azerbaijan and Armenia. Global Journal of Humanities and Social Science 11(7).

Bagehot W (1873) Lombard street (1962 edition) San Francisco, CA USA, Homewood, IL Richard D. Irwin

Barua S, Rana RH (2015) Financial development and economic growth: evidence from a panel study on south Asian countries. Asian Econ Financ Rev 5(10):1159-1173

Barajas A, Chami R, Fullenkamp C, Peter JM (2009) Do workers' remittances promote economic growth, IMF working paper no. 09/153, publication@inf.org.

Beijer G (1970) International and national migratory movements. Int Migr 8(3):93-109

Binford L (2003) Migrant remittances and (under) development in Mexico. Crit Anthropol 23(3):305-336

Blouchoutzi A, Nikas C (2014) Emigrants' remittances and economic growth in small transition economies: the cases of Moldova and Albania. East-West J Econ Bus 18(2)

Chami R, Fullenkamp C, Jahjah S (2003) Are immigrant remittances flows a source of capital for development? International Monetary Fund, Working paper WP/03/189

Chenery HB, Stout A (1996) Foreign assistance and economic development. Am Econ Rev 55:679-733

Chowdhury M (2016) Financial development, remittances and economic growth: evidence using dynamic panel estimation. J Appl Econ Res 10(1):35-54

Cooray A (2012) Migrant remittances, financial market development and the government ownership of banks: evidence from a group of non-OECD economies. J Int Financ Mark Inst Money 22(4):936-957

Coulibaly D (2015) Remittances and financial development in sub-saharan African countries: a system approach. Econ Model 45:249-258

De Haas, H (2007) Remittances, migration and social development: A conceptual review of the literature. Social Policy and Development Programme, Paper No. 34. Geneva: UNRISD.

De Haas H (2010) Migration and development: a theoretical perspective. Int Migr Rev 44(1):227-264

Dickey DA, Fuller WA (1979) Distribution of the estimators for autoregressive time series with a unit root. J Am Stat Assoc 74:427-431

Dickson OO, Eshenake SJ (2013) Financial openness and economic growth in Nigeria: a vector error correction approach. An Int Multi-Disciplinary J Ethiopia 7(4):79-92

Esteves R, Khoudour-casteras D (2011) Remittances, capital flows and financial development during the mass migrantion period. European Review of Economic History 15, Pp. 443-474.

Faini R (2005) Migration, remittances and growth: poverty, international migration and asylum studies in development economics and policy. Palgrave Macmillan, London https://doi.org/10.1057/9780230522534_8

Fayissa B, Nsiah C (2010) Can remittances spur economic growth and development?. Evidence from Latin American countries (LACS). Department of Economics and Finance Working Paper Series

Feeny S, lamsiraroj S, Mc Gillivray M (2014) Remittances and economic growth: larger impacts in smaller countries? J Dev Stud 50(8):1055-1066. https://doi.org/10.1080/100220388.2014.895815

Freund C, Spatafora N (2008) Remittances, transaction costs, and informality. J Dev Econ 86(2):356-366

Gazdar, K and Kratou, H, (2012) Institutions financial development and the remittances growth nexus in Africa. Journal of Economic Literature - American Economic Association.

Giuliani P, Ruiz Arranz M (2005) Remittances, financial development and growth IMF Working paper 05/234, International Monetary Fund, Washington DC, USA

Giuliani P, Ruiz Arranz M (2009) Remittances, financial development and growth. J Dev Econ 90(1):144-152

Goschin Z (2013) The remittances as a potential economic growth resource for Romania. Faculty of Sciences, Annales universitatis apulensis series oeconomica. 15(2): 655-661

Im KS, Pesaran MH, Shin Y (2003) Testing for unit roots in heterogeneous panels. J Econ 115:53-74

Imai KS et al. (2014) Remittances, growth and poverty: new evidence from Asian countries, Journal of Policy Modeling, http://dx.doi. org/10/1016/j.jpolmod.2014.01.009. New evidence from Asian countries. International Fund for Agricultural Development (IFAD)

International migration report 2015, United Nation, Geneva, Switzerland, Accessed August 2018.

Javid M, Arif U, Abdul Q (2012) Impact of remittances on economic growth and poverty. Acad Res Int 2(1) 
Jayaraman TK, Choong CK, Kumar RR (2011) Financial sector development and remittances in Pacific Island economies. How do they help the world's two most recipient-dependent countries? Perspect Global Dev Technol 10(3-4): $386-405$

Jayaraman TK, Choong CK, Kumar RR (2012) Role of remittances in India's economic growth. Global Bus Econ Rev 14(3) Kao C (1999) Spurious regression and residual-based tests for cointegration in panel data. J Econ 90:1-44 Karagoz K (2009) Workers' remittances and economic growth: evidence from Turkey. J Yasar Univ 4(13):1891-1908 Karikari NK, Mensah S, Harvey SK (2016) Do remittances promote financial development in Africa? Springer Plus 5: 1-21. https://doi.org/10.1186/s40064-016-2658-7.

Khan A, Azam M (2011) Workers' Remittances and Economic Growth: Evidence from Azerbaijan and Armenia. Global J Hum Soc Sci 11(7) Kibet KS, Agbelenko FA (2015) Financial development and economic growth in west African economic and monetary union (WAEMU). Afr J Bus Manag 9(17):624-632

Kindleberger CP (1965) Europe's postwar growth: the role of labor supply. Oxford University Press, New York, USA

Koay YY, Choong CK (2013) The nexus between worker remittances and economic growth in Malaysia, Prosiding Perkem VIII,JILID 1,Pp.507-515, ISSN:2231-962X

Kratou H, Gazdar K (2016) Addressing the effect of workers' remittance on economic growth: evidence from MENA countries. Int J Soc Econ 43(1):51-70. https://doi.org/10.1108/IJSE-08-2013-0189

Kumar RR (2012) Exploring the interactive effects of remittances, financial development and ICT in sub-Saharan Africa: an ARDL bound approach. Afr J Econ Sustain Dev 1(3)

Kumar RR (2013) Remittances and economic growth: a study of Guyana. Econ Syst 37(3):462-472

Kumar RR, Vu HT (2014) Exploring the nexus between ICT, remittances and economic growth: a study of Vietnam. Journal of Southeast Asian Economies (JSEAE) ISEAS-YUSOF Ishak Institute, 31(1), Pp. 104-120.

Kumar, R.R., Stanvermann P.J. (2014) Exploring the effects of remittances on Lithuanian economic growth.25(21):3 Engineering Economics. https://doi.org/10.5755/jol.ee.25.3.6421

Levin A, Lin CF, Chu C (2002) Unit root tests in panel data: asymptotic and finite-sample properties. J Econ 108:1-24

Levine R, Loayza N, Beck T (2000) Financial intermediation and growth: causality and causes. J Monet Econ 46(1):31-77

Lipton M (1980) Migration from the rural areas of poor countries: the impact on rural productivity and income distribution. World Dev 8(1):1-24

Mamingi N, Perch J (2013) Population growth and economic growth/development: an empirical investigation for Barbados. $J$ Econ Sustain Dev 4(4):93-105

Massey DS, Arango J, Hugo G, Kouaouci A, Pellegrino A, Taylor JE (1993) Theories of international migration: a review and appraisal. Popul Dev Rev 19(3):431-466

Mckinnon Rl, Shaw E (1973) Money, capital and banking on economic development. Brooklyn institution, Washington D.C

Metu AG, Chinedua N (2015) Financial development and economic growth nexus in Nigeria. J Econ Finance 6(4):49-56

Meyer D, Shera A (2013) Remittances and their impact on economic growth. Soc Manag Sci 21(1):3-19

Migration and Remittances 2016, Washington, DC, World Bank, USA

Motelle SI (2011) The role of remittances in financial development in Lesotho: evidence from alternative measures of financial development. J Dev Agric Econ 3(6):241-251

Ndikumana L, Lutz MB (2007) The growth effects of openness to trade and the role of institutions: New evidence from African countries. University of Massachusetts Amherst

Nyamongo EM, Misati RN, Kipyegon L, Lydia N (2012) Remittances, financial development and economic growth in Africa, J Econ Bus, Elsevier, 64(3), pp. 240-260

Nzotta SM, Ezeabasili VN, Alajekwu UB (2013) Trade openness, stock market development and economic growth of Nigeria: empirical evidence. Res J Finance Acc 4(3):120-127

Olufemi A, Ayandibu A (2014) Impact of remittances on development in Nigeria: challenges and prospects. J Soc Anthropol 5(3):311-318

Pearce OT, Pelesai AN (2013) Financial development and economic growth in Nigeria. Eur J Bus Manag 15(19):69-81

Pedroni P (1999) Critical values for Cointegration tests in heterogeneous panels with multiple Regressors. Oxf Bull Econ Stat 61:653-670

Pesaran HM (2004) General diagnostic tests for cross-section dependence in panels. Faculty of Eco:1-39. https://doi.org/10. 17863/CAM.5113

Pesaran, MH (2007) A simple panel unit root test in the presence of cross-section dependence. Journal of Applied Econometrics, John Wiley and Sons.

Pesaran MH, Shin Y (1995) An autoregressive distributed lag modeling approach to cointegration analysis. Cambridge WOrking Papers in Economics 9514, Faculty of Economics, University of Cambridge.

Pesaran MH, Shin Y, Smith RJ (1999) Pooled mean group estimation of dynamic heterogeneous panels. J Am Stat Assoc 94:621-634

Pesaran MH, Shin Y, Smith RJ (2001) Bound testing approaches to the analysis of level relationships. J Appl Econ 16:289-326

Phillips PCB, Perron P (1988) Testing for a unit in time series regression. Biometrica 75:335-346. https://doi.org/10.1093/ biomet/7.52.335

Praise G, Bahle M, Precious L (2014) Impact of financial liberalization on economic growth: a case study of South Africa. Mediterranean J Soc Sci 5(23):238-245

Ratha D (2013) The impact of remittances on economic growth and poverty reduction. Migration Policy Institute. No. 8 , September 2013

Richard H, Adams RH, Page J (2005) Do international migration and remittances reduce poverty in developing countries? World Dev 33(10):1645-1669

Rubenstein H (1992) Migration. Development and remittances in rural Mexico. Int Migr 30(2):1992

Russell S. S (1992) "Migrant Remittances and Development." International Migration, 30(3-4):267-87.

Sarker B, Datta K (2014) Relationship between remittances and economic growth in Bangladesh: an econometric study. Bangladesh Development Research Centre (BDRC) USA, http://www.bangladeshstudies.org/wps/

Schumpeter JA (1911) The theory of economic development. Cambridge, Harvard university press. USA

Sibindi AB (2014) Remittances, financial development and economic growth: empirical evidence from Lesotho. J Gov Regul 3(4):116-124 
Siddique A, Selvanathan EA, Selvanathan S (2010) Remittances and economic growth: empirical evidence from Bangladesh, India and Sri Lanka. The university of Western Australia. Discussion paper 10.27

Sobiech I(2015) Remittances, finance and growth: does financial development foster remittances and their impact on economic growth?, FIW Working Paper Series, No 158

The Economist International Monetary Fund, (2018) www.economist.com Accessed Apr 2018

Todaro MP (1969) A model of labor migration and urban unemployment in less developed countries. Am Econ Rev 59:138-148

Todaro MP, Smith, SC (2012)'Economic Development'. $11^{\text {th }}$ Edition

World Bank (2014) Migration and Development Brief Issue 22, Washington D.C.: World Bank

World Bank (2017) Washington DC United States

World Development Indicator (2015) "The world Bank 1818 H street N.W. Washington, D.C" 20433. USA

World Development Indicator (2017). The World Bank 1818 H Street N.W. Washington, D.C, 20433. USA.

Yaseen HS (2012) The positive and negative impact of remittances on economic growth in MENA countries. J Int Manag Stud 7(1)

Yin Koay Y, Keong Choong C (2013) The nexus between workers' remittances and economic growth in Malaysia. Prosiding Perkem J 8(1):507-515

Submit your manuscript to a SpringerOpen ${ }^{\circ}$ journal and benefit from:

- Convenient online submission

Rigorous peer review

- Open access: articles freely available online

- High visibility within the field

- Retaining the copyright to your article

Submit your next manuscript at $\boldsymbol{\nabla}$ springeropen.com 